\section{STUDENT PROFILE}

1. TOtAL RECRUited: 20

DROPOUTS :

1

2. SOURCES OF RECRUITMENT:

\begin{abstract}
7 transferred from within the college
\end{abstract}
13 applied as direct entries

3. EXPERIENCED PROFESSIONAL WRITERS: 8

4. DEGREES OR DIPLOMAS HELD:

Diploma, Electrical Engineering: 1

Diploma, Computer Programming: 2

Diploma, Radio and TV Arts: 1

Engineering degree and/or P.Eng.: 3

Bachelor of Science:

Bachelor of Journalism:

Bachelor of Commerce:

5. PERSONAL PROFILE:

$\begin{array}{ll}11 \text { married, } & 9 \text { single } \\ 15 \text { male, } & 5 \text { female } \\ \text { Age : } 23-24 & 6 \\ 25-28 & 10 \\ & \text { over 28 } \\ \end{array}$

\section{WRITING A CANADIAN ADAPTATION}

Dixie Stockmayer

Business Communication: Strategles and Skills by Richard C. Huseman, James M. Lahiff and John D. Hatfleld, I111no1s: Dryden Press, 1981, $431 \mathrm{PP}$.

In May 1982, when I accepted an Invitation to prepare a Canadian adaptation of the Huseman et al text, Business Communication, I was unprepared for what lay before me over the next two years: deadInes that seemed reasonable when I agreed to them initlally rushed by; a task that I anticipated might take three or four hours would take three or four times as long; changes which appeared easy were not. However, I belleve that the product justifies the planning and hard work which the adaptation required.

\section{PLANNING THE ADAPTATION}

The obvious changes required in the Canadian adaptation were, of course:

-the use of the metric system

-the replacement of American spellings, usage, and examples with Canadian material

However, I was also asked to review the text to Identify its major strengths and weaknesses with specific reference to:

1. the coverage given to particular topics or areas

-should the coverage of certain topics be expanded? abbreviated? or deleted?

-should new topic areas be expanded?

2. the number and nature of the examples in the original text -are there suffictent examples?

- to what extent are specifically Canadian examples or applicatlons needed? 
PROPOSED CONTENT CHANGES

My own experience and the results of a survey of Canadian users Indicated that several areas required modification:

-Part 1, "Theoretical Considerations", duplicated content from other business courses

-the chapter on "Effective Written Communication" needed more information on the writing process

-material on letter and memo format was burled in the chapter on

"Good News and Neutral Letters"

-the chapter on "Formal Reports" needed more Information and clarification

-Part 3, "Oral Strategies" needed to focus and expand on listening ski1ls and public presentations

-the chapter on Job Search Letters and Interviews needed to focus more on the covering letter

-additional exercises were needed at the end of each chapter.

\section{THE REVISION PROCESS}

If nothing else, I learned a lot about the metric system from this project. For someone who took her last Math course in Grade 12 and used Grade 13 Latin instead of Math for university entrance, this was no mean feat. I'd become accustomed to calculating distances and speed in kilometers, and I knew how much cheese or meat I could expect to get if $I$ ordered $250 \mathrm{grams}$. However, newtons, tonnes and metric size of a standard bond paper $(21.5 \mathrm{~cm}$ by $27.9 \mathrm{~cm})$ were beyond me.

Most of the examples and case studies required minimal changes for the Canadian adaptation. By changing place names, adding postal codes, and changing situations like "baseball camp" to "hockey camp", I felt they would be relevant to Canadian students. Here, balancing the number of cases set in each province became one of the main objectives.

At times, more complete changes were required. For example, in the chapter on resumes, references to legislation had to be adapted to the Canadian situation:

-because being fluently bilingual in Prench and English is an advantage in applying for a job in the federal civil service or in areas with a significant Francophone population, that ability was emphasized.

-because human rights legislation varies from one jurisdiction to another, a general statement was required

\section{THE CANADIAN EDITION}

The Canadian edition of Business Communication still approaches the teaching of communication skills from the perspective of the total communication process--writing, speaking, and listening--but all examples, applications, and exercises are now set in the Canadian context, ensuring that the material is even more relevant, realistic, and interesting for Canadian students.

The Canadian edition has added:

-new material on the writing process, and researching and writing reports

-more detalled instructions on preparing an effective public presentation

-a chapter on letter and memo format

-a step-by-step guide to obtaining a job, paying particular attention to the covering letter

Moreover, the positive layout features of the original 1981 American edition are retained:

-clear and informative headings

-learning objectives at the beginning of each chapter -margin notes on important points

-checklists for memos, letters, reports, and public presentations -revlew questions at the end of each chapter

And, most 1mportantly, the paperback format has reduced the cost significantly.

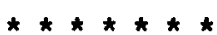

Dixie Stockmayer graduated with a B.A. (Honours) from Victorla College, the University of Toronto in 1971. Since 1980 she has been an instructor In the English Department of the British Columbia Institute of Technology, Burnaby, teaching communication to varlous business and health technology students. 